\title{
ARTICLE
}

\section{Antibody-based PET imaging of amyloid beta in mouse models of Alzheimer's disease}

Dag Sehlin ${ }^{1}$, Xiaotian T. Fang ${ }^{1}$, Linda Cato ${ }^{1}$, Gunnar Antoni ${ }^{2,3}$, Lars Lannfelt ${ }^{1} \&$ Stina Syvänen ${ }^{1}$

Owing to their specificity and high-affinity binding, monoclonal antibodies have potential as positron emission tomography (PET) radioligands and are currently used to image various targets in peripheral organs. However, in the central nervous system, antibody uptake is limited by the blood-brain barrier (BBB). Here we present a PET ligand to be used for diagnosis and evaluation of treatment effects in Alzheimer's disease. The amyloid $\beta$ ( $A \beta$ ) antibody mAb158 is radiolabelled and conjugated to a transferrin receptor antibody to enable receptor-mediated transcytosis across the BBB. PET imaging of two different mouse models with $A \beta$ pathology clearly visualize $A \beta$ in the brain. The PET signal increases with age and correlates closely with brain $A \beta$ levels. Thus, we demonstrate that antibody-based PET ligands can be successfully used for brain imaging.

\footnotetext{
${ }^{1}$ Department of Public Health and Caring Sciences/Geriatrics, Uppsala University, Rudbeck Laboratory, 75185 Uppsala, Sweden. ${ }^{2}$ Department of Medicina Chemistry, Preclinical PET Platform, Uppsala University, 75123 Uppsala, Sweden. ${ }^{3}$ PET Centre, Uppsala University Hospital, 75185 Uppsala, Sweden. Correspondence and requests for materials should be addressed to S.S. (email: stina.syvanen@pubcare.uu.se).
} 
P ositron emission tomography (PET) imaging of amyloid $\beta$ $(\mathrm{A} \beta)$ deposits in the brain has rapidly advanced in recent years. The introduction of the radioligand $\left[{ }^{11} \mathrm{C}\right] \mathrm{PIB}$ (ref. 1), a derivate of thioflavin-T, was an important development for diagnosis of Alzheimer's disease (AD), as $\left[{ }^{11} \mathrm{C}\right] \mathrm{PIB}$ amyloid imaging detects $\mathrm{AD}$ pathology early in the course of disease $\mathrm{e}^{2}$ and helps distinguishing $\mathrm{AD}$ from other types of dementia ${ }^{3,4}$. $\left[{ }^{11} \mathrm{C}\right] \mathrm{PIB}$, and analogues of PIB, detect amyloid plaques, mainly consisting of insoluble fibrils of $A \beta$ (ref. 1). However, the load of insoluble $A \beta$ does not correlate well with disease progression ${ }^{5,6}$. Soluble $A \beta$ is a better marker of disease status ${ }^{7-10}$, and many therapeutic as well as diagnostic efforts are currently targeting soluble $A \beta$ aggregates, for example, oligomers and protofibrils ${ }^{11-17}$, which are strongly implicated as the cause of synaptic failure and neurodegeneration in $\mathrm{AD}^{9,10,18-23}$. This new focus highlights the pressing need for an imaging agent that can visualize soluble $\mathrm{A} \beta$ aggregates. The development of small molecular PET radioligands often suffers from nonspecific binding of the radioligand, and further, low ability to discriminate between different forms of a protein. Radioligands based on antibodies have recently been introduced in clinical use for various peripheral antigens primarily related to cancer $^{24}$. Antibodies have the advantage that they can be developed to bind a specific form of a protein, but their use as PET radioligands for targets in the central nervous system (CNS) is hampered by their low brain penetration. However, whereas a high enough brain uptake is essential to achieve a PET signal, the specific-to-nonspecific binding, expected to be very high for a monoclonal antibody compared with small molecules, may be equally important.

Our previously developed conformation-selective monoclonal antibody mAb158 displays a distinctive selectivity for soluble $A \beta$ protofibrils as compared with monomeric $A \beta$. It binds preferentially to soluble protofibrils over mature, insoluble fibrils, but without affinity for the $A \beta$ protein precursor $(\mathrm{A} \beta \mathrm{PP})^{25-28}$. These characteristics make the antibody suitable to selectively target soluble $\mathrm{A} \beta$ aggregates in vivo, and its humanized version, BAN2401, (hereafter referred to as h158), is currently studied in a phase $2 \mathrm{~b}$ clinical trial as an anti-A $\beta$ therapy against $\mathrm{AD}$. In a previous study we showed that $72 \mathrm{~h}$ after administration, the brain concentrations of iodine-125-labelled mAb158 ([ $\left.{ }^{125} \mathrm{I}\right]$ mAb158) was significantly increased in a transgenic $\mathrm{AD}$ mouse model (tg-ArcSwe, harbouring the Arctic (E693G) and Swedish (KM670/671NL) A PPP mutations ${ }^{29}$ ) compared with non-transgenic littermates (wild type; WT) ${ }^{27}$. However, total levels of $\left[{ }^{125} \mathrm{I}\right] \mathrm{mAb} 158$ in the brain were rather moderate, which is anticipated for antibodies in general ${ }^{30}$.

Different strategies have been applied to increase the brain uptake of antibodies and other large molecules. Among them is receptor-mediated transcytosis, where the antibody is fused to a molecule that specifically binds to a blood-brain barrier (BBB) expressed receptor, for example, the transferrin or insulin receptor, which enables active transport across the BBB (Fig. 1a). This technique was pioneered by Pardridge and colleagues ${ }^{31}$ in the 1990s, and has recently been implemented in AD therapy to decrease production ${ }^{32,33}$ or increase degradation ${ }^{34}$ of $A \beta$.

In the present study, a $\mathrm{F}\left(\mathrm{ab}^{\prime}\right)_{2}$ fragment of h158 is chemically fused to a transferrin receptor (TfR) antibody ${ }^{35}$ with the aim to create a PET ligand for specific imaging of soluble $A \beta$ protofibrils. Brain retention of the generated bispecific fusion protein increases 15-fold, compared with $\mathrm{F}\left(\mathrm{ab}^{\prime}\right)_{2}$-h158. We then show by PET imaging that the brain distribution of ${ }^{124}$ I-labelled fusion protein correlates closely with the age-dependent increase of A $\beta$ pathology in the brains of two transgenic mouse models with $\mathrm{AD}$-like pathology. This new radioligand has the potential to become an important diagnostic tool in $\mathrm{AD}$ and furthermore, the study demonstrates that bispecific radioligands based on antibodies can be applied in medical imaging of proteins associated with CNS disorders.

\section{Results}

Engineering of an A $\beta$-TfR bispecific fusion protein. A PET ligand with a fairly short systemic half-life is desired since a rapid elimination from the blood increases the specific signal compared with the background, derived from the blood volume of the studied tissue (about 5\% in brain) and decreases the radiation dose for the patient. Therefore, $\mathrm{a} F\left(\mathrm{ab}^{\prime}\right)_{2}$ fragment was generated by enzymatic cleavage of h158, reducing its systemic half-life to $\sim 2 \mathrm{~h}$ in both tg-ArcSwe and WT mice, compared with 11 days for mAb158 (ref. 27). The A $\beta$-binding properties of $F\left(\mathrm{ab}^{\prime}\right)_{2}-\mathrm{h} 158$ were unchanged, compared with the parent antibody. To increase brain uptake of $\mathrm{F}\left(\mathrm{ab}^{\prime}\right)_{2}$-h158, it was chemically conjugated to the anti-TfR antibody 8D3 (ref. 36), which has been widely used to increase the brain uptake of large molecules ${ }^{34,37-40}$.

The $8 \mathrm{D} 3-\mathrm{F}\left(\mathrm{ab}^{\prime}\right)_{2}-\mathrm{h} 158$ fusion protein was sufficiently pure for the intended purpose (Fig. 1b). The difference in fusion protein binding in solution to $A \beta$ monomer, protofibril and fibril, reflected by their ability to inhibit the fusion protein's binding to an $A \beta$-coated enzyme-linked immunosorbent assay (ELISA) a

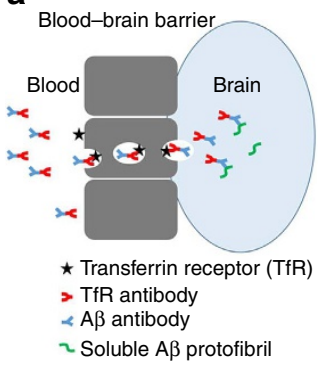

b

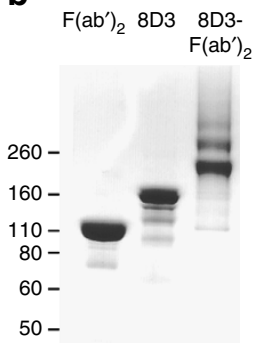

C

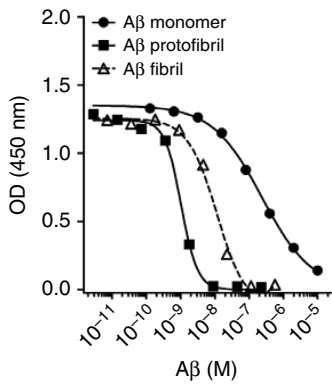

d

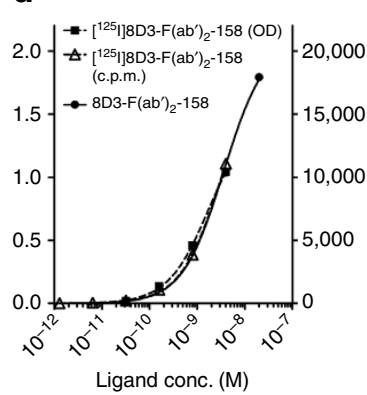

e

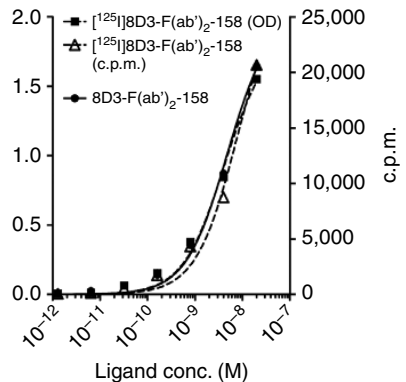

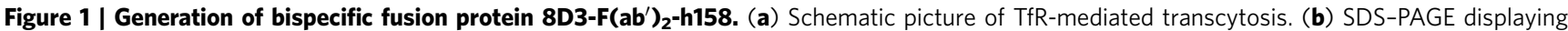
$\mathrm{F}\left(\mathrm{ab}^{\prime}\right)_{2}$-h158, TfR antibody 8D3 and the fusion protein consisting of $\mathrm{F}\left(\mathrm{ab} \mathrm{b}^{\prime}\right)_{2}-\mathrm{h} 158$ and $8 \mathrm{D} 3$. (c) Inhibition ELISA demonstrating the fusion protein's selective binding to $A \beta$ protofibrils ( $I C_{50} 1.0 \mathrm{nM}$ ) over fibrils ( $\mathrm{CC}_{50} 12 \mathrm{nM}$ ) and monomers $\left(\mathrm{IC}_{50} 240 \mathrm{nM}\right)$. The fusion protein showed retained binding to TfR (d) and $A \beta$ protofibrils (e) after ${ }^{125}$ l labelling, as demonstrated with ELISA (absorbance values on the left $y$ axis and radioactivity on the right $y$ axis). Representative images from triplicate experiments are shown in c-e. conc., concentration; c.p.m., counts per minute; IC 50 , median inhibitory concentration; $\mathrm{OD}_{\text {, optical }}$ density; SDS-PAGE, SDS-polyacrylamide gel electrophoresis. 
plate, was very similar to what we have previously reported for mAb158 (refs 25,27), with median inhibitory concentration values of $240 \mathrm{nM}$ for monomers, $1.0 \mathrm{nM}$ for protofibrils and $12 \mathrm{nM}$ for fibrils (Fig. 1c). Furthermore, it retained its binding to both $\mathrm{TfR}$ and $\mathrm{A} \beta$ protofibrils also after radioiodination (Fig. 1d,e).

Increased brain uptake by $\mathrm{TfR}$-mediated transcytosis. The pharmacokinetic blood profile of the radioiodinated fusion protein $\left[{ }^{125} \mathrm{I}\right] 8 \mathrm{D} 3-\mathrm{F}\left(\mathrm{ab}^{\prime}\right)_{2}-\mathrm{h} 158$ was the same in tg-ArcSwe and WT mice displaying a half-life of $11 \mathrm{~h}$ (Fig. 2a). For successful PET imaging, it is important to have a high brain uptake of the ligand in relation to its concentration in blood. Therefore, the brain-to-blood ratio $\left(K_{\mathrm{p}}\right)$ of the fusion protein was assessed by ex vivo studies at three different time points. Radioactivity was measured in blood and saline-perfused brains of $>12$-month-old tg-ArcSwe and WT mice, killed 4, 24 and $72 \mathrm{~h}$ after intraperitoneal (i.p.) injection of $\left[{ }^{125} \mathrm{I}\right] 8 \mathrm{D} 3-\mathrm{F}\left(\mathrm{ab}^{\prime}\right)_{2}-\mathrm{h} 158$. At $4 \mathrm{~h}$ $K_{\mathrm{p}}$ was low $(0.02 \pm 0.01)$, with no difference between tg-ArcSwe and WT mice. $K_{\mathrm{p}}$ had increased at $24 \mathrm{~h}$ and was significantly different $(P<0.05)$ between the groups. At $72 \mathrm{~h}$ post injection, $K_{\mathrm{p}}$ had further increased to $0.44 \pm 0.10(P<0.001)$ in tg-ArcSwe, while the WT mice were stable on a low level (Fig. 2b). The fusion protein transport into the brain was assessed in $>18$-month-old mice at 4 and $2 \mathrm{~h}$, corresponding to $C_{\max }$ of the fusion protein and the $\mathrm{F}\left(\mathrm{ab}^{\prime}\right)_{2}$ fragment in blood, respectively, and measured as per cent of injected dose per gram brain tissue (\% ID per g). At this point, the fusion protein was taken up ninefold more than $\left.{ }^{125} \mathrm{I}\right] \mathrm{F}\left(\mathrm{ab}^{\prime}\right)_{2}-\mathrm{h} 158$, with no difference between tg-ArcSwe and WT mice (Fig. 2c). When studied $72 \mathrm{~h}$ post injection, that is, at the highest $K_{\mathrm{p}}$ of the fusion protein, it showed a 15 -fold higher brain retention in tg-ArcSwe mice than the $\mathrm{F}\left(\mathrm{ab}^{\prime}\right)_{2}$ fragment and a greater difference between tg-ArcSwe and WT mice (Fig. 2d).

To assess whether the transport across the $\mathrm{BBB}$ may be mediated by the Fc receptor, 10- to 12-month-old WT and tg-ArcSwe mice were injected with ${ }^{125}$ I-labelled $8 \mathrm{D} 3$ or a Fab fragment of 8D3 (Fab-8D3), which lacks the Fc fragment, and ex vivo brain uptake was measured $4 \mathrm{~h}$ post injection. Fab-8D3 was equally well distributed to the brain as $8 \mathrm{D} 3$, strongly indicating that the high brain concentrations observed with $8 \mathrm{D} 3$ and the fusion protein were due to TfR-mediated transcytosis and independent of the Fc domain of the 8D3 antibody (Fig. 3a).
As an additional control, a fusion protein consisting of 8D3 and a $\mathrm{F}\left(\mathrm{ab}^{\prime}\right)_{2}$ fragment of an antibody (Synagis; specific for the respiratory syncytial virus) of the same IgG isoform as h158, but lacking a specific target in the brain, was also generated. The generated $8 \mathrm{D} 3-\mathrm{F}\left(\mathrm{ab}^{\prime}\right)_{2}$-Synagis fusion protein retained its binding to TfR, but did not bind to $A \beta$ protofibrils (Fig. $3 b, c)$.

Ex vivo studies were also performed with the irrelevant fusion protein $\left[{ }^{125} \mathrm{I}\right] 8 \mathrm{D} 3-\mathrm{F}\left(\mathrm{ab}^{\prime}\right)_{2}$-Synagis, which had a similar half-life in blood as $\left[{ }^{125} \mathrm{I}\right] 8 \mathrm{D} 3-\mathrm{F}\left(\mathrm{ab}^{\prime}\right)_{2}-\mathrm{h} 158$. Similar to $8 \mathrm{D} 3$, the brain retention of the irrelevant fusion protein was elevated in WT mice $4 \mathrm{~h}$ post injection. At $72 \mathrm{~h}$ post injection, the brain retention of the irrelevant fusion protein was the same in tg-ArcSwe and WT mice (Fig. 3d,e) and of the same magnitude as observed with $\left.{ }^{125} \mathrm{I}\right] 8 \mathrm{D} 3-\mathrm{F}\left(\mathrm{ab}^{\prime}\right)_{2}-\mathrm{h} 158$ in WT mice.

These experiments demonstrated that compared with $\mathrm{F}\left(\mathrm{ab}^{\prime}\right)_{2}-\mathrm{h} 158$, the fusion protein transport into the brain was markedly increased in both tg-ArcSwe and WT mice. Hence, the carrier-mediated transcytosis was not dependent on animal type or age. However, in WT animals, lacking A $\beta$ protofibrils, the fusion protein was washed out from the brain when systemic concentrations decreased. Similarly, $\left[{ }^{125} \mathrm{I}\right] 8 \mathrm{D} 3-\mathrm{F}\left(\mathrm{ab}^{\prime}\right)_{2}$-Synagis, which lacks a protofibril-binding domain, was eliminated from the brains of both WT and tg-ArcSwe mice when the blood concentration decreased. As a consequence of the fairly rapid systemic elimination of the fusion protein, $K_{\mathrm{p}}$ increased in tg-ArcSwe mice over time, but not in WT mice. Moreover, when compared with the whole antibody mAb158 (ref. 27), $K_{\mathrm{p}}$ of the fusion protein was more than 20-fold increased $72 \mathrm{~h}$ post injection.

Brain retention follows $\mathbf{A} \boldsymbol{\beta}$ pathology in transgenic mice. The brain retention of the fusion protein was measured ex vivo $72 \mathrm{~h}$ post injection in saline-perfused brains of tg-ArcSwe and WT mice at 4,12 and $>18$ months of age to follow the course of $\mathrm{A} \beta$ pathology. Brain levels of soluble $A \beta$ protofibrils as well as total (formic acid soluble) $A \beta 40$ and $A \beta 42$ were determined in the same mice. We have previously established that total $A \beta$, measured by ELISA, closely matches A $\beta$ plaque load as determined with immunohistochemistry in tg-ArcSwe mice ${ }^{27}$. There was a significant difference in brain retention of the fusion protein between tg-ArcSwe and WT mice at 12 months (3.5-fold) and $>18$ months (6.8-fold), as well as a trend towards increased a

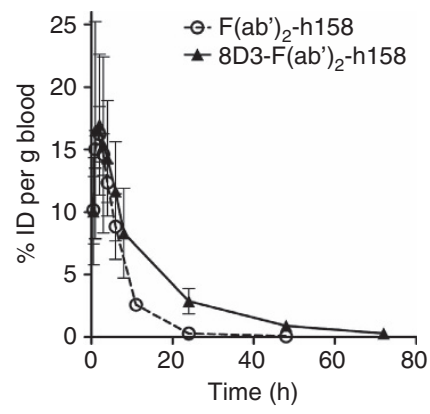

b

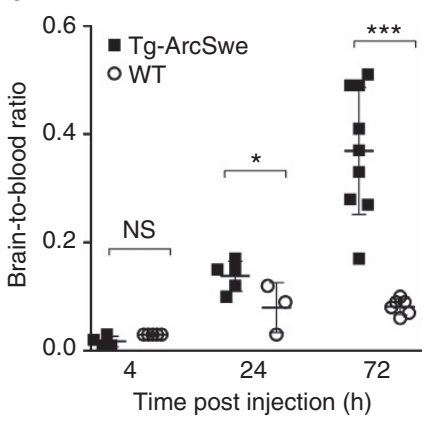

c

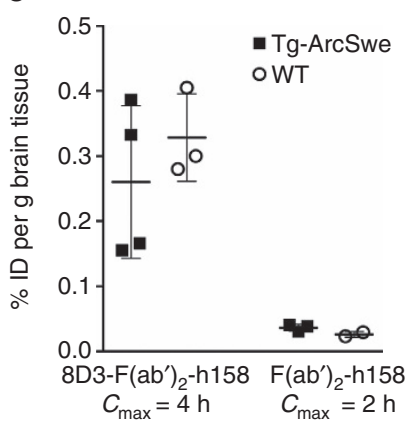

d

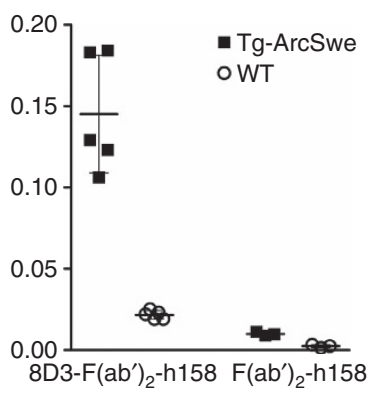

Figure 2 | In vivo blood pharmacokinetics and brain distribution of fusion protein in tg-ArcSwe and WT mice. (a) The bispecific fusion protein (triangles, $n=6$ ) showed an increased half-life (11 h) compared with unmodified $F\left(a b^{\prime}\right)_{2}$-h158 (circles, $n=3 ; 2 h$ ). (b) The brain-to-blood concentration ratio of the fusion protein increased over time in tg-ArcSwe mice ( $>12$ months, $n=18$ ) while remaining fairly constant in WT mice $(n=14)$. (c) Comparison of brain distribution of fusion protein $(n=7)$ and unmodified $\mathrm{F}\left(\mathrm{ab}^{\prime}\right)_{2}$-h158 $(n=5)$ at respective $C_{\max }$. At this time point the increase in brain distribution mainly reflected increased transport across the BBB as the increase was observed both in tg-ArcSwe and WT mice ( $>18$ months). (d) Comparison of brain distribution of fusion protein $(n=10)$ and unmodified $\mathrm{F}\left(\mathrm{ab}^{\prime}\right)_{2}-\mathrm{h} 158(n=6) 72 \mathrm{~h}$ post injection. At this time point the differences observed between tg-ArcSwe and WT mice ( $>18$ months) reflected binding to $A \beta$ protofibrils. The symbols and error bars indicate group mean \pm s.d. from experiments (a). Each symbol represents one animal, line and error bars indicate group mean \pm s.d. (b-d). ${ }^{\star} P<0.05$, ${ }^{\star \star \star} P<0.001$ and NS is nonsignificant by two-way analysis of variance followed by Bonferroni's post hoc test (b). 

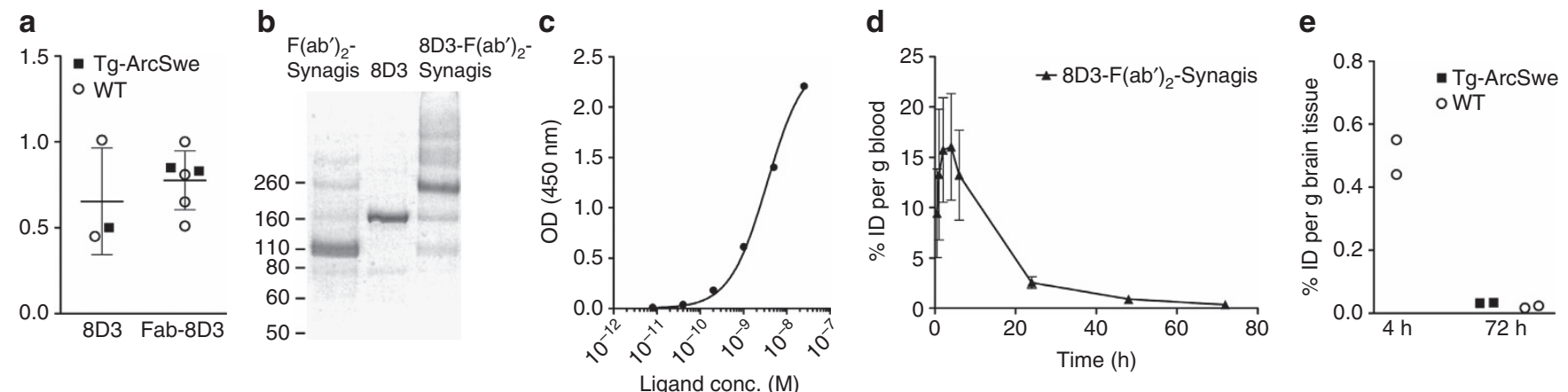

Figure 3 | Brain distribution of 8D3 and generation of an A $\boldsymbol{\beta}$ irrelevant fusion protein. (a) Brain distribution of $8 \mathrm{D} 3(n=3)$ and Fab-8D3 ( $n=6)$ in $10-$ to 12-month-old WT and tg-ArcSwe mice 4h post injection, demonstrating that the TfR-mediated transcytosis of 8D3 is Fc-independent. (b) SDS-PAGE displaying $\mathrm{F}\left(a b^{\prime}\right)_{2}$-Synagis, TfR antibody 8D3 and the fusion protein consisting of $\mathrm{F}\left(\mathrm{ab} \mathrm{b}^{\prime}\right)_{2}$-Synagis and 8D3. (c) TfR ELISA demonstrating that the irrelevant fusion protein binds to TfR in vitro. (d) In vivo blood pharmacokinetics of irrelevant fusion protein in tg-ArcSwe $(n=2)$ and WT mice $(n=4)$ : the irrelevant fusion protein showed a similar half-life as the $8 \mathrm{D} 3-\mathrm{F}\left(\mathrm{ab} \mathrm{b}_{2}\right)_{2}-\mathrm{h} 158$ fusion protein $(11 \mathrm{~h})$. (e) Comparison of irrelevant fusion brain concentration at $4 \mathrm{~h}\left(\mathrm{C}_{\text {max }}\right)$, demonstrating an increased transport across the BBB in WT mice $(n=2)$, and at $72 \mathrm{~h}$ post injection, where the low concentration of irrelevant fusion protein in both tg-ArcSwe $(n=2)$ and WT $(n=2)$ mice reflects the lack of target in the brain. The symbols and error bars indicate group mean \pm s.d. (d). Each symbol represents one animal (a and $\mathbf{e}$ ). SDS-PAGE, SDS-polyacrylamide gel electrophoresis.

brain concentrations also in the 4-month group (1.3-fold) (Fig. 4a and Table 1). The WT animals showed constant brain concentrations of fusion protein regardless of age. Both soluble $A \beta$ protofibrils and total $A \beta 40$ and $A \beta 42$ increased over time in tg-ArcSwe mice, displaying elevated levels of $A \beta$ protofibrils already at 4 months (Fig. $4 \mathrm{~b}$ ). The increase over time in soluble $A \beta$ protofibril levels correlated closely with the brain concentrations of fusion protein (Fig. 4c), while total $A \beta$ concentrations increased with a higher rate (Fig. 4d) suggesting that the $A \beta$ targeted by the fusion protein was mainly of soluble origin. To rule out the possibility that the ligand might be stuck in the endothelium and not transported into the brain, staining for the endothelial marker CD31 in combination with nuclear track emulsion was used to visualize the fusion protein in the brain. The fusion protein was found in the brain parenchyma without accumulation in capillaries in $>18$-month-old tg-ArcSwe mice (Fig. 4e) but to some extent clustered around the periphery of congophilic amyloid deposits, suggesting it was bound to a halo of soluble $A \beta$ aggregates, which has been reported to surround the fibrillar core of amyloid plaques ${ }^{41}$ (Fig. $4 \mathrm{f}$ ).

In vivo PET imaging of A $\beta$ pathology in transgenic mice. Next, to evaluate the fusion protein as a PET ligand, it was labelled with ${ }^{124}$ I, a positron-emitting radionuclide with a half-life of 4.2 days. Tg-ArcSwe and WT mice of different ages $(4,8,12$ and 18 months) as well as tg-Swe mice (12 and 18 months), with a delayed age at onset of pathology compared with tg-ArcSwe ${ }^{29,42}$, were injected i.p. with $\left.\sim 15 \mathrm{MBq}{ }^{[124} \mathrm{I}\right] 8 \mathrm{D} 3-\mathrm{F}\left(\mathrm{ab}^{\prime}\right)_{2}$-h158 and PET scanned for $60 \mathrm{~min} 72 \mathrm{~h}$ post injection. $A \beta$ pathology could be clearly visualized in the 12- and 18-month-old tg-ArcSwe mice while there was no signal in the WT mice (Fig. 5a). In tg-Swe mice, no specific signal was recorded at 12 months, whereas a strong signal was seen at 18 months, confirming that the signal seen in tg-ArcSwe mice was not an effect of the Arctic A $\beta$ PP mutation. In a subset of the animals, ex vivo autoradiography was performed, as a comparison to the results of brain distribution seen in the PET images. Clinical PET data, including studies using $\left[{ }^{11} \mathrm{C}\right] \mathrm{PIB}$, is often quantified as the relative concentration of the PET ligand in a region of interest to that of a reference region. When analysing the present PET data from the whole brain, cortex, hippocampus, striatum and thalamus using the cerebellum as a reference region, the obtained ratio followed the disease progression in all studied regions (Fig. 5b). The cerebellum displayed a low PET signal in all animals at all ages
(Fig. 5a) confirming its suitability as a reference region. Deiodination of the fusion protein, measured in plasma after PET scanning, was $<5 \%$.

To verify that neurodegenerative pathology characterized by protein aggregation per se did not lead to increased retention of $\quad\left[{ }^{124} \mathrm{I}\right] 8 \mathrm{D} 3-\mathrm{F}\left(\mathrm{ab}^{\prime}\right)_{2}-\mathrm{h} 158, \quad$ 18-month-old (Thy-1)-h[A30P] $\alpha$-synuclein transgenic mice (hereafter referred to as tg- $\alpha$-syn) were also PET scanned according to the same protocol. The $\operatorname{tg}-\alpha$-syn mice, like the WT mice, displayed no signal in the brain (Fig. 5c). In addition, to confirm that the differences in brain retention observed between $\mathrm{AD}$ and WT mice were not due to increased binding of the 8D3 moiety in the brains of tg-ArcSwe and tg-Swe mice, 18-month-old tg-ArcSwe and WT mice were injected with $\sim 15 \mathrm{MBq}$ of the irrelevant fusion protein $\left.{ }^{[124} \mathrm{I}\right] 8 \mathrm{D} 3-\mathrm{F}\left(\mathrm{ab}^{\prime}\right)_{2}$-Synagis and PET scanned for $60 \mathrm{~min} 72 \mathrm{~h}$ post injection. No accumulation in brain could be observed in either mouse type (Fig. 5d), and when quantified, the concentration ratios in all studied brain regions in relation to cerebellum were around 1 (Fig. 5b), confirming that the higher brain concentrations observed with $\left[{ }^{124} \mathrm{I}\right] 8 \mathrm{D} 3-\mathrm{F}\left(\mathrm{ab}^{\prime}\right)_{2}-\mathrm{h} 158$ in tg-ArcSwe and tg-Swe compared with WT mice were indeed due to the $A \beta$ protofibril-binding moiety $F\left(a^{\prime}\right)_{2}-h 158$.

PET imaging correlates with soluble A $\beta$ protofibrils. Brains from the mice subjected to PET imaging were analysed for Tris-buffered saline (TBS)-soluble $A \beta$ protofibrils and total (formic acid-soluble) $A \beta 40$ and $A \beta 42$. Cerebellum and the rest of the brain were analysed separately to enable a direct comparison with PET results. As displayed in Fig. 6a, cerebellum contained overall very low levels of $A \beta$ protofibrils, but more importantly, no increase was seen with increased age in either tg-ArcSwe or tg-Swe mice in direct analogy with PET results. In the rest of the brain, $A \beta$ protofibril levels increased with age after 8 months in tg-ArcSwe, showing elevated levels at 12 months, that is, at the same age as $A \beta$ was detectable with PET, that were further increased at 18 months. The same pattern was observed for the tg-Swe animals, although the increase was seen between 12 and 18 months. Hence, there was no overlap in $A \beta$ protofibril levels between PET-positive and PET-negative animals, which allows to define a PET detection limit completely separating the groups (Fig. 6a). For total $A \beta 40$ and $A \beta 42$, the pattern was different in tg-ArcSwe mice, with a marked increase in brain $\mathrm{A} \beta$ concentrations already at 8 months, continuing up to 12 months and then forming a plateau. Interestingly, unlike soluble $A \beta$ protofibril 
a

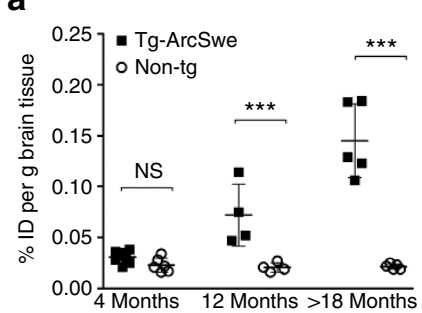

d

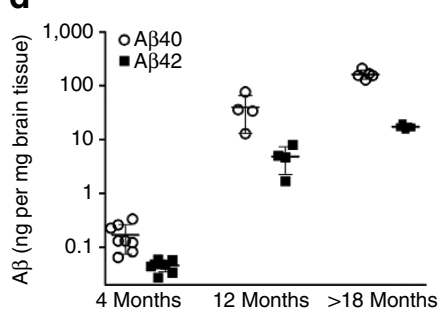

b

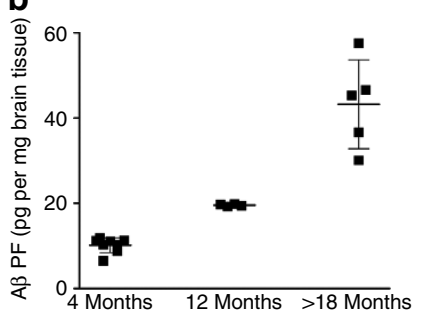

e

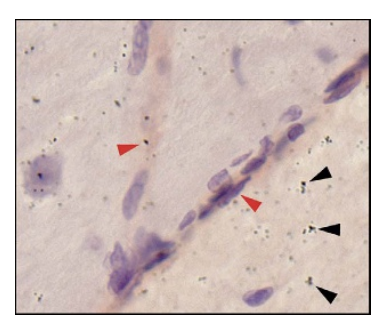

C

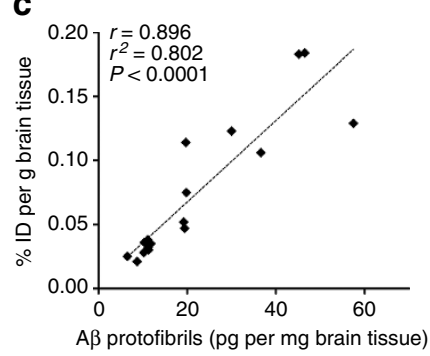

f

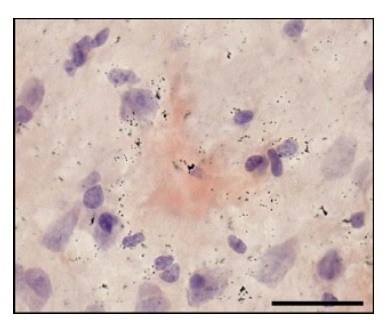

Figure 4 | Age-dependent retention of fusion protein in brain. (a) Ex vivo brain retention expressed as \% ID per g brain tissue in tg-ArcSwe ( $n=17$ ) and WT $(n=15)$ mice of different ages $72 \mathrm{~h}$ post injection. (b) A $\beta$ protofibril levels in brain tissue obtained from tg-ArcSwe mice of different ages. (c) Pearson's correlation analysis of brain concentrations of fusion protein $72 \mathrm{~h}$ post injection and concentration of $\mathrm{A} \beta$ protofibrils in brain tissue of tg-ArcSwe mice. Each diamond represents one animal. (d) Total $A \beta 40$ and A $\beta 42$ levels in brain tissue from tg-ArcSwe mice of different ages. (e) Nuclear track emulsion and CD31 staining. The fusion protein was not accumulated in capillaries (red arrows) but to a large extent reached the brain parenchyma (black arrows).

(f) Nuclear track emulsion and Congo staining revealed that the fusion protein was also located around insoluble amyloid deposits. Scale bar, $50 \mu \mathrm{m}$. Each symbol represents one animal, the line and error bars (a-d) indicate group mean \pm s.d. ${ }^{\star \star \star} P<0.001$ and NS is nonsignificant by two-way analysis of variance followed by Bonferroni's post hoc test (a). Representative images from triplicate experiments are shown in $\mathbf{e}$ and $\mathbf{f}$.

Table 1 | Ex vivo brain concentration of $\left[{ }^{125} \mid\right] 8 D 3-F\left(a b^{\prime}\right)_{2}-h 158$ at $72 \mathrm{~h}$ post injection.

\begin{tabular}{|c|c|c|c|c|}
\hline 4 & $0.03 \pm 0.01$ & $0.02 \pm 0.01$ & $0.10 \pm 0.01$ & $0.09 \pm 0.02$ \\
\hline$>18$ & $0.14 \pm 0.04^{\star \star \star}$ & $0.02 \pm 0.00$ & $0.44 \pm 0.10^{\star \star \star \star}$ & $0.06 \pm 0.01$ \\
\hline
\end{tabular}

levels, total $A \beta 40$ and $A \beta 42$ levels increased with age also in the cerebellum, though with several months delay (Fig. 6b,c). The tgSwe model showed a large increase in total $A \beta$ at 18 months compared with 12 months, but low levels in the cerebellum at both ages, possibly because of its later onset of $A \beta$ pathology (Fig. 6b,c). For comparison with the PET data, a brain/cerebellum ratio of the three different $A \beta$ species was plotted against the brain/cerebellum PET ratio described above (Fig. 6d-f). The tgSwe animals were excluded from the $A \beta 40$ and $A \beta 42$ ratio graphs since they had extremely high ratios, caused by the low $A \beta$ levels in cerebellum. Whereas a strong correlation was seen between the $A \beta$ protofibril and $P E T$ ratios, the total $A \beta$ ratios did not correlate with PET data.

Comparison with $\left[{ }^{11} \mathrm{C}\right]$ PIB. A subset of the mice that underwent PET scanning with the fusion protein was also imaged with $\left[{ }^{11} \mathrm{C}\right] \mathrm{PIB}$ to compare the two ligands in mice with different $\mathrm{A} \beta$ pathology (Fig. 7). The 8- and 12-month-old transgenic animals showed similar $\left[{ }^{11} \mathrm{C}\right] \mathrm{PIB}$ retention in brain as WT animals. The 18-month-old tg-ArcSwe and tg-Swe mice showed some $\left[{ }^{11} \mathrm{C}\right] \mathrm{PIB}$ retention, mainly in cortical regions, but the brain/cerebellum ratio was in general lower than the ratio obtained with the fusion protein and did not reflect the disease progression to the same extent as the fusion protein did. Radioactivity concentration (corrected for injected dose) of $\left[{ }^{11} \mathrm{C}\right] \mathrm{PIB}$ and $\left[{ }^{124} \mathrm{I}\right] 8 \mathrm{D} 3-\mathrm{F}\left(\mathrm{ab}^{\prime}\right)_{2^{-}}$ h158 was similar in 18-month-old tg-ArcSwe brain (Fig. 7a), while tg-Swe mice showed $60 \%$ higher concentration of $\left[{ }^{124} \mathrm{I}\right] 8 \mathrm{D} 3-\mathrm{F}\left(\mathrm{ab}^{\prime}\right)_{2}-\mathrm{h} 158$ than of $\left[{ }^{11} \mathrm{C}\right] \mathrm{PIB}$ (Fig. $7 \mathrm{~b}$ ).

\section{Discussion}

Several new drug compounds intended for treatment of AD have entered clinical phase II and III studies, but there are limited possibilities to measure their effects on the molecular level in vivo. All existing amyloid PET radioligands bind to the $\beta$-sheet structure of insoluble fibrillar $A \beta$. Evidence today points to soluble forms of aggregated $A \beta$ being better correlated with disease severity and soluble $A \beta$ oligomers and protofibrils are likely to cause the synaptic failure that eventually leads to dementia. The present study shows for the first time an in vivo PET image of A $\beta$ pathology acquired with an antibody-based radioligand (Fig. 5). This was achieved by a combination of TfR-mediated transcytosis to increase $\mathrm{BBB}$ penetration and the use of a well-characterized $A \beta$ protofibril selective antibody, which ensures that $\mathrm{A} \beta$ aggregates are selectively targeted. Although mAb158 binds, albeit with a lesser affinity, to $A \beta$ fibrils and monomers in vitro ${ }^{25,27}$ (Fig. 1c), evidence suggests that 

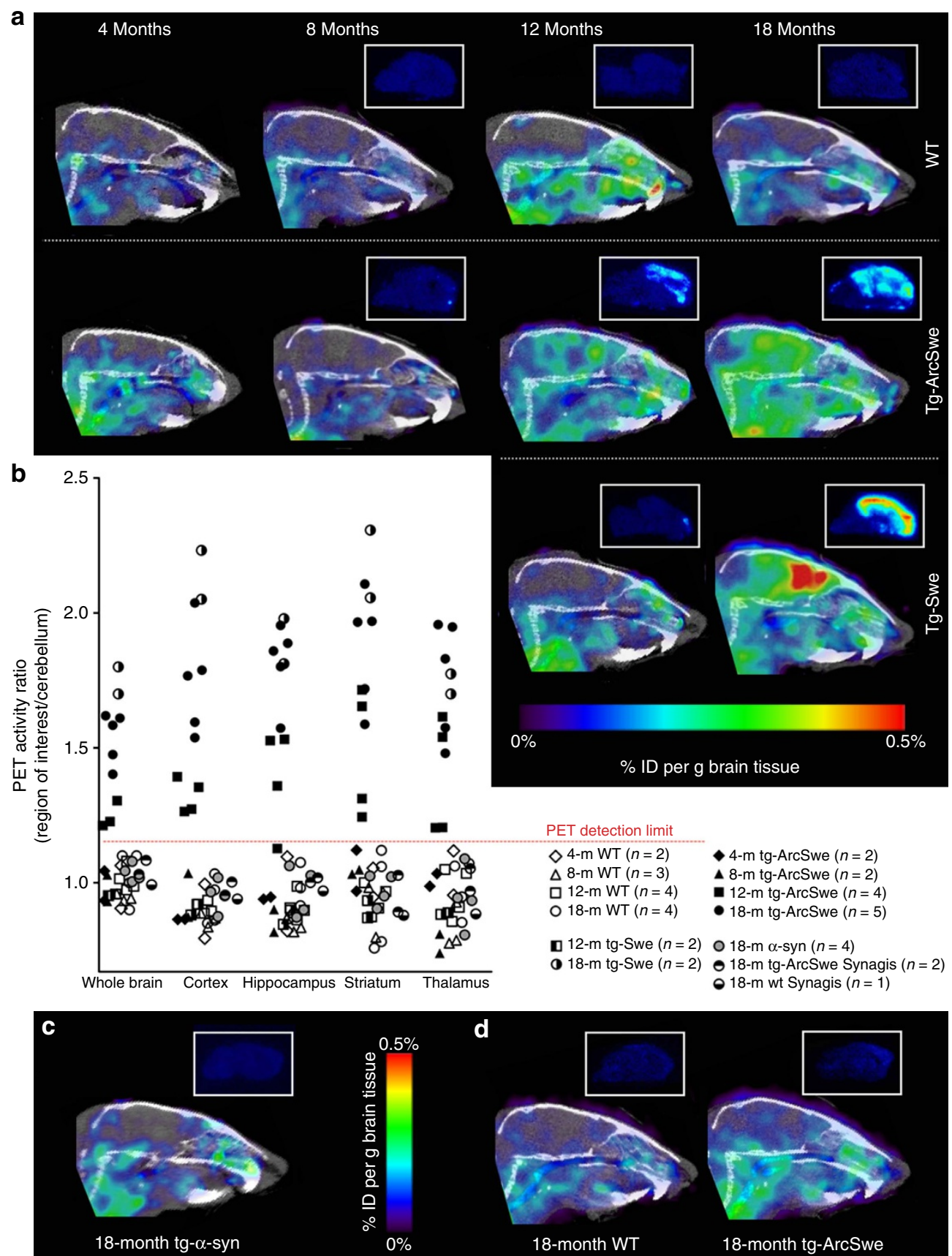

Figure 5 | Fusion protein PET imaging in transgenic and WT mice. (a) Comparison of PET images obtained during 60 min, $72 \mathrm{~h}$ post injection of ${ }^{[24}$ I] 8D3-F $\left(a b^{\prime}\right)_{2}$-h158 from representative WT, tg-ArcSwe and tg-Swe mice of different ages, demonstrating the progression of $A \beta$ pathology. Ex vivo autoradiography brain images from the same animals are displayed above PET images for comparison of brain distribution. (b) PET image-based quantification of brain distribution of the fusion protein relative to that in cerebellum for WT, tg-ArcSwe, tg-Swe and tg- $\alpha$-syn mice in the different age groups (each symbol represents one animal). (c) PET image of 18-month-old tg- $\alpha$-syn mouse, $72 \mathrm{~h}$ post injection of $\left[{ }^{124}\right.$ I] $8 D 3-\mathrm{F}\left(\right.$ ab') ${ }_{2}$-h158. (d) PET images obtained with the irrelevant $\left[{ }^{124} \mathrm{I}\right] 8 \mathrm{D} 3-\mathrm{F}\left(\mathrm{ab}^{\prime}\right)_{2}$-Synagis $72 \mathrm{~h}$ post injection, with ex vivo autoradiography brain images from the same animals displayed above, demonstrating low and equal brain uptake in 18-month-old WT and tg-ArcSwe mice. Representative PET images are shown in a,c and d. Number of animals included in each group is shown in $\mathbf{b}$.

it primarily targets soluble $\mathrm{A} \beta$ protofibrils in vivo. When administered to tg-ArcSwe mice with plaque pathology, mAb158 selectively reduced brain levels of $A \beta$ protofibrils, without altering the plaque pathology ${ }^{43}$, unlike other $A \beta$ antibodies of the same isotype ${ }^{44}$. This is probably because soluble A $\beta$ protofibrils, which are already favoured by mAb158, are more accessible to the antibody when it enters the brain parenchyma than the insoluble fibrils deposited in plaques. This is also reflected in Fig. 4e,f, where in vivo administered fusion protein appears in the parenchyma and around the periphery of plaques, where $A \beta$ oligomerization has been reported to occur ${ }^{41}$.

Further, the PET signal and brain retention of the generated bispecific fusion protein increased with age (Fig. 5), that is, with progression of $\mathrm{A} \beta$ pathology in the tg-ArcSwe and tg-Swe mouse models. Tg-ArcSwe mice exhibit very dense A $\beta$ plaque pathology, similar to that of the human AD brain, with an onset around 6 
a

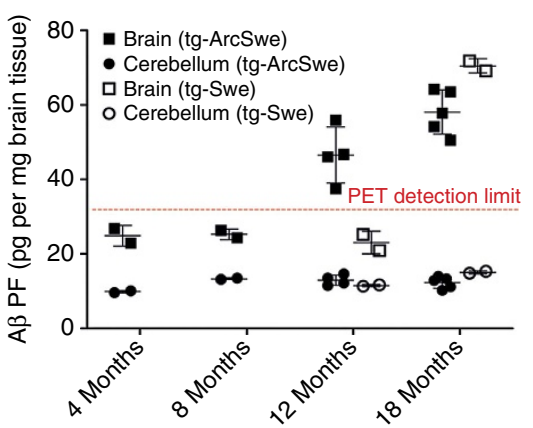

d

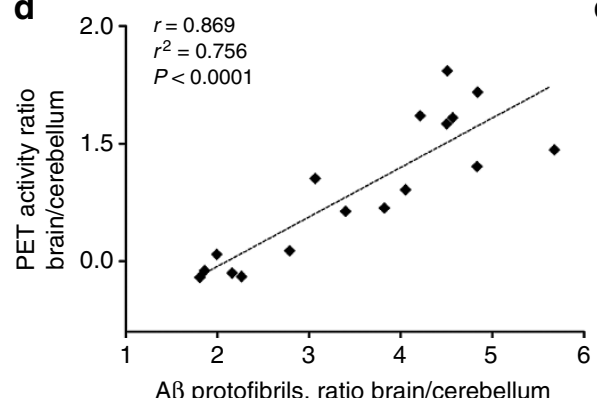

b

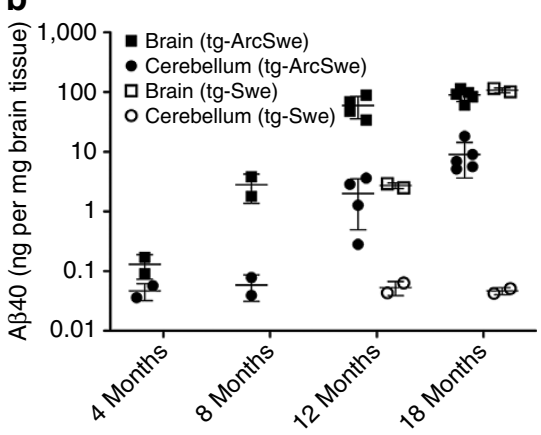

e

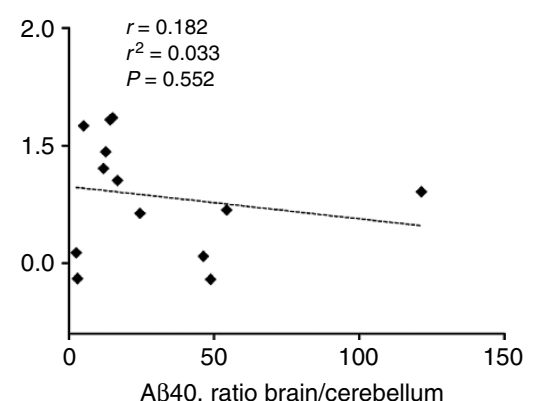

C

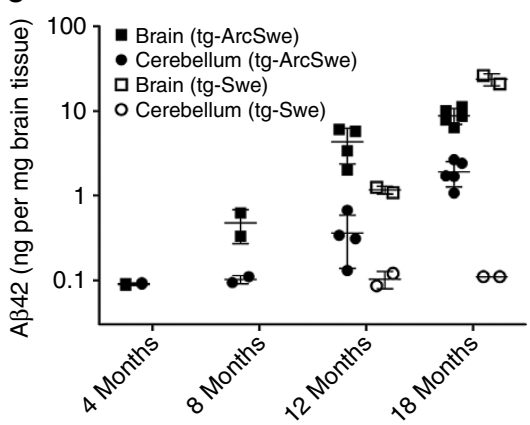

$\mathbf{f}$

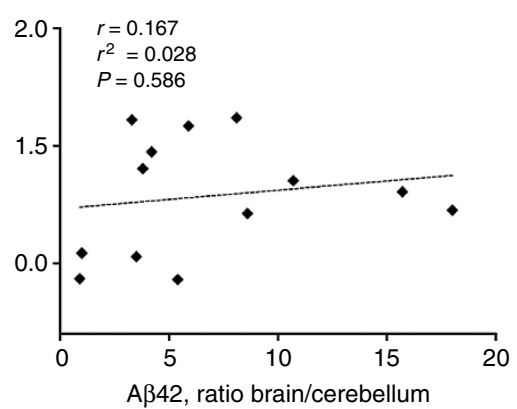

Figure 6 | A $\beta$ levels in brain and cerebellum and correlation with PET data. (a) A $\beta$ protofibril (PF) levels in brain tissue obtained from tg-ArcSwe ( $n=13$ ) and tg-Swe $(n=4)$ mice of different ages; total $A \beta 40(\mathbf{b})$ and $A \beta 42(\mathbf{c})$ levels in brain and cerebellum from tg-ArcSwe and tg-Swe mice of different ages; Pearson's correlation analysis of brain/cerebellum PET ratio and brain/cerebellum concentration ratio of soluble A $\beta$ protofibrils in tg-ArcSwe and tg-Swe mice (d) and of total $A \beta 40$ (e) and $A \beta 42$ (f) in tg-ArcSwe mice. Each symbol represents one animal previously subjected to PET scanning; the line and error bars $(\mathbf{a}-\mathbf{c})$ indicate group mean \pm s.d.

months of age ${ }^{42}$, and an almost linear increase of soluble $\mathrm{A} \beta$ protofibrils with age (Figs 4 and 6). Tg-Swe mice display less dense plaques ${ }^{42}$ with a later onset and a more rapid increase in $\mathrm{A} \beta$ pathology (Fig. 6). Hence, at 12 months of age, higher concentrations of $\left[{ }^{124} \mathrm{I}\right] 8 \mathrm{D} 3-\mathrm{F}\left(\mathrm{ab}^{\prime}\right)_{2}-\mathrm{h} 158$ was observed in the brains of tg-ArcSwe compared with tg-Swe mice, while the opposite was observed at 18 months. The difference between the two animal models was also evident in the $\left[{ }^{11} \mathrm{C}\right] \mathrm{PIB}$ scans. $\left[{ }^{11} \mathrm{C}\right] \mathrm{PIB}$ binds poorly to the loose unstructured plaques in tg-Swe mice brain and thus $\left[{ }^{11} \mathrm{C}\right] \mathrm{PIB}$ concentrations were lower than $\left.{ }^{124} \mathrm{I}\right] 8 \mathrm{D} 3-\mathrm{F}\left(\mathrm{ab}^{\prime}\right)_{2}$-h158 in tg-Swe mice, while the concentration of the two radioligands was similar in tg-ArcSwe brain. Brain retention of the fusion protein correlated closely with brain concentrations of soluble $A \beta$ protofibrils in both animal models (Fig. 4), while total $A \beta$ levels, reflecting the plaque pathology, increased at a higher rate, suggesting that the fusion protein preferably binds to soluble $A \beta$ protofibrils. Furthermore, low radioactivity was detected with PET in the cerebellum in all age groups, while it increased with age in the rest of the brain. Similarly, while the level of soluble $A \beta$ protofibrils increased with age in the whole brain, cerebellum displayed a low and constant level of protofibrils over time. Thus, the PET brain/cerebellum radioactivity concentration ratio, which is often used in clinical PET as a read-out measure, correlated with the brain/cerebellum ratio of soluble $A \beta$ protofibrils (Fig. 6). Such a correlation was not seen for total $A \beta$, since both $A \beta 40$ and $A \beta 42$ increased with age in the cerebellum. These results do not per se exclude that the radioligand may also to some extent bind to fibrillar $A \beta$ in the brain, possibly in the shape of diffuse deposits.

Taken together, our findings suggest that brain retention of the fusion protein measured with PET reflects the progression of A $\beta$ pathology. This approach could become an important diagnostic tool to predict disease stage in $\mathrm{AD}$ patients, likely including the group of patients displaying mainly diffuse plaque pathology 45 that are diagnosed falsely as non-AD with the available amyloid PET radioligands ${ }^{46}$. Treatment strategies to reduce soluble A $\beta$ aggregates are today studied in late-phase clinical trials, but biomarkers for evaluating the effects of such treatments need to be improved. A PET radioligand visualizing soluble A $\beta$ aggregates could bring substantial benefit in assessing emerging $A \beta$-reducing treatments.

To our knowledge this is the first successful study using an antibody-based PET ligand for a CNS application. Since antibodies are very specific binders, the drawback of large unspecific binding often experienced with small molecular PET ligands (including $\left[{ }^{11} \mathrm{C}\right] \mathrm{PIB}$ and analogues) will most likely be avoided with antibody-based ligands. This study therefore also demonstrates the feasibility of antibody-based in vivo imaging of proteins involved in other neurodegenerative disorders, for example, Parkinson's disease or frontotemporal lobar degeneration, for which small molecular PET ligands are currently lacking.

\section{Methods}

Antibody fragmentation. $\mathrm{F}\left(\mathrm{ab}^{\prime}\right)_{2}$-h158 was generated by cleavage of a humanized variant, BAN2401, of the mouse monoclonal antibody mAb158, selectively binding to $A \beta$ protofibrils, that is, soluble $A \beta$ aggregates larger than about $100 \mathrm{kD}$, eluting in the void volume on a Size Exclusion Superdex 75 column $^{25}$. The bacterial enzyme IdeS (ref. 47), manufactured and distributed as FabRICATOR (Genovis $\mathrm{AB}$, Lund, Sweden), was used to cleave the antibody. This enzyme cleaves human IgG at a specific site just below the hinge region, producing a homogenous preparation of $\mathrm{F}\left(\mathrm{ab}^{\prime}\right)_{2}$ fragments. A $\mathrm{F}\left(\mathrm{ab}^{\prime}\right)_{2}$ fragment of an antibody against respiratory syncytial virus, Synagis (Palivizumab; 530300, Apoteket AB, Solna, Sweden/MedImmune, Gaithersburg, MD, USA), was generated according to the same method. Fab-8D3 was generated from the TfR antibody 8D3 (ref. 36) (MCA2474, AbD Serotec, Oxford, UK) by papain cleavage, according to the manufacturer's protocol (Pierce, Rockford, IL, USA).

All fragments were purified with CaptureSelect $F_{c}$ (multi-species) Affinity Resin (Thermo Fisher Scientific, Stockholm, Sweden) to remove Fc fragments and non-cleaved antibody from the preparation. Purity and size of the fragments were evaluated with SDS-PAGE under non-reducing conditions. Briefly, samples were mixed with Laemmli buffer, loaded onto a Novex pre-cast $10-20 \%$ Tris-tricine 


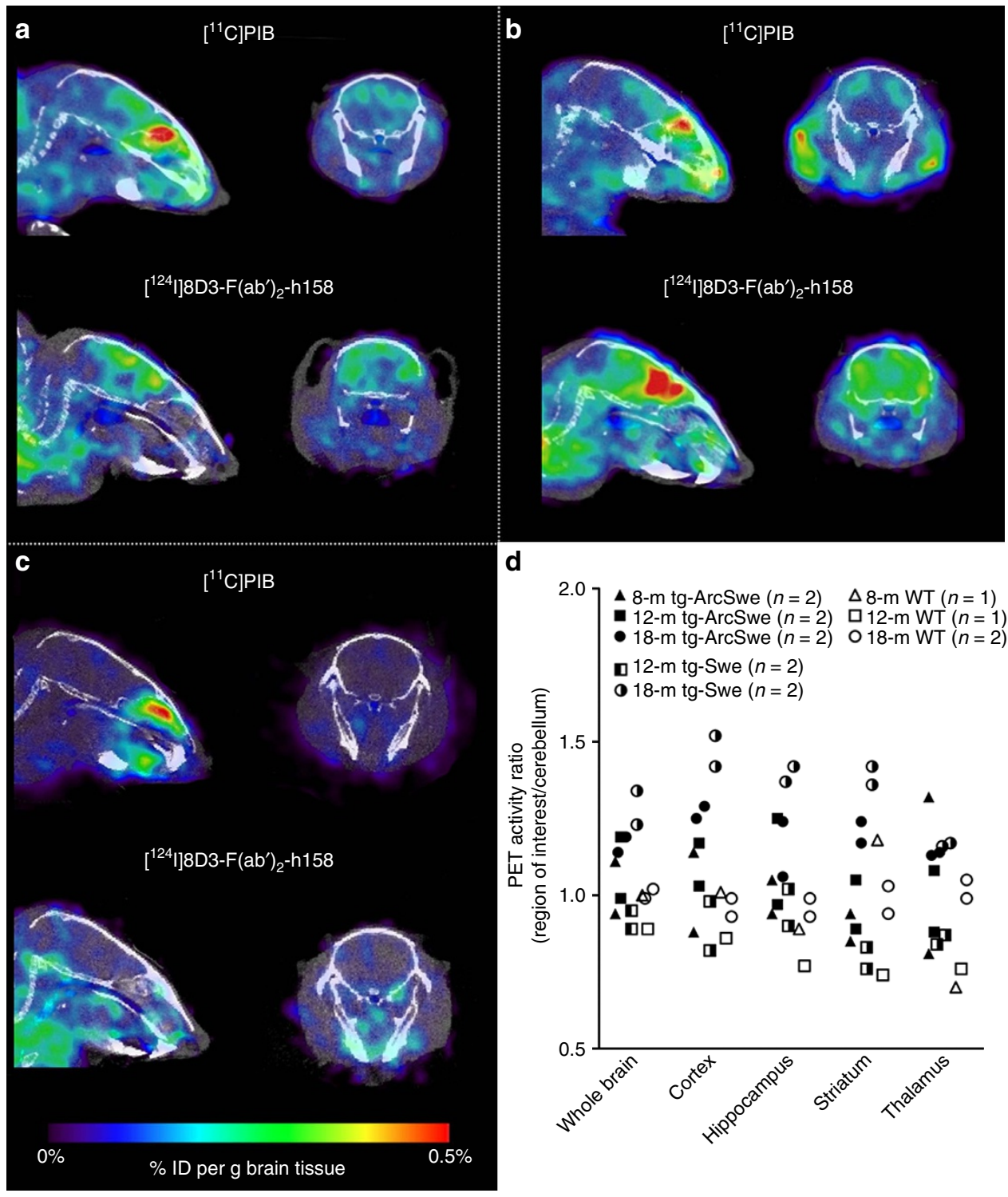

Figure 7 | Comparison of PET imaging with [ ${ }^{\mathbf{1 1}} \mathbf{C}$ ]PIB- and ${ }^{\mathbf{1 2 4}}$ I-labelled fusion protein in transgenic and WT mice. PET images obtained during 60 min $72 \mathrm{~h}$ after injection of $\left[{ }^{124} \mathrm{I}\right] 8 \mathrm{D} 3-\mathrm{F}\left(\mathrm{ab}^{\prime}\right)_{2}-\mathrm{h} 158$, or during $20 \mathrm{~min}$, starting $40 \mathrm{~min}$ after injection of $\left.{ }^{11} \mathrm{C}\right] \mathrm{PIB}$. Transverse and sagittal views of one representative 18-month-old tg-ArcSwe (a), tg-Swe (b) and WT (c) mouse with the two radioligands. (d) PET image-based quantification of brain distribution of $\left[{ }^{11} \mathrm{C}\right] \mathrm{PIB}$ relative to that in cerebellum for tg-ArcSwe, tg-Swe and WT mice in the different age groups (each symbol represents one animal). Representative PET images are shown in a-c. Number of animals included in each group is shown in $\mathbf{d}$.

polyacrylamide gel (Invitrogen, Carlsbad, CA) and run at $125 \mathrm{~V}$ for $90 \mathrm{~min}$, followed by $3 \times 15$-min wash in water, and staining with Page Blue

(Fermentas, Vilnius, Lithuania) according to the manufacturer's instructions.

Generation of bispecific fusion proteins. $\mathrm{F}\left(\mathrm{ab}^{\prime}\right)_{2}-\mathrm{h} 158$ or $\mathrm{F}\left(\mathrm{ab}^{\prime}\right)_{2}$-Synagis and 8D3 were chemically conjugated with the Solulink technology (Solulink protein conjugation kit; Solulink, San Diego, CA, USA), where each of the conjugated proteins is modified with one of two linkers, which bind specifically to each other to form a permanent bond. $\mathrm{F}\left(\mathrm{ab}^{\prime}\right)_{2}-\mathrm{h} 158$ or $\mathrm{F}\left(\mathrm{ab}^{\prime}\right)_{2}$-Synagis $\left(3.0 \mathrm{mg} \mathrm{ml}^{-1}\right)$ was labelled with succinimidyl-4-formylbenzamide (S-4FB) using a 4.5-fold molar excess, and $8 \mathrm{D} 3\left(3.0 \mathrm{mg} \mathrm{ml}^{-1}\right)$ was labelled with the complimentary succinimidyl6-hydrazino-nicotinamide (S-HyNic) using a 6-fold molar excess. The labelled proteins were mixed in a 1.5:1 $\left(\mathrm{F}\left(\mathrm{ab}^{\prime}\right)_{2}: 8 \mathrm{D} 3\right)$ molar ratio and reacted for $2 \mathrm{~h}$ in room temperature in the presence of $10 \mathrm{mM}$ aniline, which catalyses the reaction. To purify the fusion protein, the preparation was incubated for $1 \mathrm{~h}$ with CaptureSelect Fc (multi-species) Affinity Matrix to specifically deplete the preparation of unconjugated $\mathrm{F}\left(\mathrm{ab}^{\prime}\right)_{2}$ fragments, which lack the $\mathrm{Fc}$ domain. After elution from the resin with $0.1 \mathrm{M}$ glycine- $\mathrm{HCl}, \mathrm{pH} 2.5$, the preparation was neutralized with $1 \mathrm{M}$ Tris and incubated for $1 \mathrm{~h}$ with CaptureSelect IgGCH1 (human) Affinity Matrix (Thermo Fisher Scientific), which specifically binds to the constant domain 1 of human IgG heavy chain, thus depleting the sample of unconjugated 8D3. The purified fusion protein was eluted with $0.1 \mathrm{M}$ glycine- $\mathrm{HCl}, \mathrm{pH} 2.5$, and analysed with SDS-PAGE as above.

A $\boldsymbol{\beta}$ inhibition ELISA. To assess the $8 \mathrm{D} 3-\mathrm{F}\left(\mathrm{ab}^{\prime}\right)_{2}-\mathrm{h} 158$ fusion protein's binding to different $A \beta$ species in solution, an inhibition ELISA was performed as previously described ${ }^{25}$. The 96 -well plates (Corning Inc., Corning, NY, USA) were coated at $+4{ }^{\circ} \mathrm{C}$ for $2 \mathrm{~h}$, with $45 \mathrm{ng}$ per well of $\mathrm{A} \beta$ protofibrils and blocked for $1 \mathrm{~h}$ with $1 \%$ bovine serum albumin (BSA) in PBS. In the meantime, the fusion protein $(0.5 \mathrm{nM})$ was incubated with serially diluted $A \beta$ monomers, protofibrils or fibrils in a nonbinding 96-well plate (Greiner, Kremsmünster, Austria) for $1 \mathrm{~h}$ on a shaker and then transferred to the $A \beta$ protofibril-coated plate, where it was incubated for $15 \mathrm{~min}$. Fusion protein bound to the plate was detected by a $1-\mathrm{h}$ incubation with 1:2,000 diluted horseradish peroxidase (HRP)-conjugated anti-human-IgG-F( $\left.\mathrm{ab}^{\prime}\right)_{2}$ (109-036-006, Jackson ImmunoResearch Laboratories, West Grove, PA, USA). Signals were developed with K blue aqueous TMB substrate (Neogen Corp., Lexington, KY, USA) and read with a spectrophotometer at $450 \mathrm{~nm}$. All $\mathrm{A} \beta$ and antibody dilutions were made in ELISA incubation buffer (PBS with $0.1 \%$ BSA $0.05 \%$ Tween and $0.15 \%$ Kathon). $A \beta$ preparations were made as previously described ${ }^{27}$ and the (insoluble) fibril preparation was subjected to a brief sonication $(30 \mathrm{~s})$ before the analysis to break-up large fibril assemblies and ensure it would stay in suspension. 
TfR-A $\beta$ protofibril ELISA. The generated $8 \mathrm{D} 3-\mathrm{F}\left(\mathrm{ab}^{\prime}\right)_{2}-\mathrm{h} 158$ fusion protein was tested with ELISA for retained binding to TfR and $A \beta$, respectively, before and after radioiodination. The 96-well plates (Corning Inc.) were coated at $+4{ }^{\circ} \mathrm{C}$ overnight with $10 \mathrm{ng}$ per well of murine TfR (Sinobiological, Beijing, China) or $25 \mathrm{ng}$ per well of streptavidin (Sigma, St. Louis, MO, USA). After $1 \mathrm{~h}$ blocking with $1 \%$ BSA in PBS, biotinylated A $\beta$ protofibrils, 4.5 ng per well, prepared as previously described $^{27}$, were added to streptavidin-coated wells and incubated for $30 \mathrm{~min}$ on a shaker. A serial dilution of the fusion protein, ${ }^{125}$ I-labelled or non-labelled, was added to TfR- or streptavidin/A $\beta$ protofibril-coated wells, incubated for $2 \mathrm{~h}$ on a shaker and detected by a 1-h incubation with HRP-conjugated 1:2,000 diluted anti-mouse-IgG-F $\left(\mathrm{ab}^{\prime}\right)_{2}$ (TfR coat) or anti-human-IgG- $\mathrm{F}\left(\mathrm{ab}^{\prime}\right)_{2}$ (streptavidin/A $\beta$ protofibril coat) (115-036-006 and 109-036-006, Jackson ImmunoResearch Laboratories). Signals were developed and read as above. All antibody dilutions were made in ELISA incubation buffer. The $8 \mathrm{D} 3-\mathrm{F}\left(\mathrm{ab}^{\prime}\right)_{2}$-Synagis fusion protein was tested for retained binding to TfR according to the same method.

Animals. Three transgenic models maintained on a C57BL/6 background were used: the tg-ArcSwe model harbouring the Arctic (AßPP E693G) and Swedish $(A \beta P P$ $K M 670 / 671 N L)$ mutations; the tg-Swe model with only the Swedish mutation; and $\operatorname{tg}-\alpha$-syn mice. Tg-ArcSwe mice show elevated levels of soluble A $\beta$ protofibrils already at a very young age and abundant and rapidly developing plaque pathology starting at around 6 months of age $29,42,48$. Tg-Swe mice have a later onset of plaque pathology starting at 10-12 months of age and then increasing with age ${ }^{42}$. Both males and females were used and littermates were used as control animals (WT). As further controls, tg- $\alpha$-syn mice displaying overexpression of human $\alpha$-synuclein (protein involved in Parkinson's disease) ${ }^{49}$ were used in the PET experiments. The animals were housed with free access to food and water in rooms with controlled temperature and humidity in an animal facility at Uppsala University.

Radiochemistry. Direct radioiodination of the four proteins $\mathrm{F}\left(\mathrm{ab}^{\prime}\right)_{2}$-h158, 8D3, $8 \mathrm{D} 3-\mathrm{F}\left(\mathrm{ab}^{\prime}\right)_{2}$-h158 and $8 \mathrm{D} 3-\mathrm{F}\left(\mathrm{ab}^{\prime}\right)_{2}$-Synagis with iodine-125 ( $\left.{ }^{125} \mathrm{I}\right)$ for ex vivo experiments and iodine-124 $\left({ }^{124} \mathrm{I}\right)$ for PET experiments was performed using Chloramine-T (ref. 50). The method is based on electrophilic attack of the phenolic ring of tyrosine residues by in situ oxidized iodine. Briefly, for ${ }^{125} \mathrm{I}$ labelling, 250 pmoles of antibody/fragment or 65 pmoles of fusion proteins (assumed $\mathrm{Mw}$ (molecular weight) $270 \mathrm{kDa}$ ), ${ }^{125}$ I stock solution (PerkinElmer Inc., Waltham, MA, USA) and $5 \mu \mathrm{g}$ Chloramine-T (Sigma Aldrich, Stockholm, Sweden) were mixed in PBS to a final volume of $110 \mu \mathrm{l}$. The reaction was allowed to proceed for $90 \mathrm{~s}$ and subsequently quenched by addition of double molar excess of sodium metabisulfite (Sigma Aldrich) and dilution to $500 \mu \mathrm{l}$ in PBS. Fab-8D3 had to be modified with Bolton Hunters reagent (Sulfo-SHPP) ${ }^{51}$ (Pierce) before radioiodination to introduce extra phenolic rings for the iodine to target. Fab-8D3 $\left(1 \mathrm{mg} \mathrm{ml}^{-1}\right.$ in PBS) was incubated for $30 \mathrm{~min}$ with $100 \times$ molar excess of sulfo-SHPP $(50 \mathrm{mM}$ in $\mathrm{H}_{2} \mathrm{O}$ ) and purified from unbound sulfo-SHPP with a Zeba mini desalting column, Mw cutoff $7 \mathrm{kDa}$ (Pierce). Modified Fab-8D3 was radiolabelled as above.

For ${ }^{124} \mathrm{I}$ labelling, $58 \mu \mathrm{ll}{ }^{124} \mathrm{I}$ stock solution (Perkin-Elmer Inc.) was preincubated for $10 \mathrm{~min}$ with $12 \mu \mathrm{l} 50 \mu \mathrm{M} \mathrm{NaI}$, before addition of 260 pmoles of fusion proteins and $40 \mu \mathrm{g}$ Chloramine-T in PBS to a final volume of $450 \mu \mathrm{l}$. The reaction was allowed to proceed for $120 \mathrm{~s}$ and subsequently quenched by addition of $80 \mu \mathrm{g}$ of sodium metabisulfite in PBS. The radiolabelled proteins were purified from free iodine and low-molecular weight components with a disposable NAP-5 size exclusion column, Mw cutoff $5 \mathrm{kDa}$ (GE Healthcare AB, Uppsala, Sweden), according to the manufacturer's instructions, and eluted in $1 \mathrm{ml}$ of PBS. The yield was calculated based on the added radioactivity and the radioactivity in the purified radioligand solution. Labelling was always performed $<2 \mathrm{~h}$ before each study. Affinity for $A \beta$ protofibrils and/or TfR was tested with ELISA on the same day as the labelling and the start of the study.

$\left[{ }^{11} \mathrm{C}\right] \mathrm{PIB}$ was synthesized as previously described ${ }^{1}$.

Injected radioactivity, specific activity, labelling reaction yields for $\mathrm{F}\left(\mathrm{ab}^{\prime}\right)_{2}-\mathrm{h} 158$, 8D3, Fab-8D3, 8D3-F( $\left(\mathrm{ab}^{\prime}\right)_{2}-\mathrm{h} 158,8 \mathrm{D} 3-\mathrm{F}\left(\mathrm{ab}^{\prime}\right)_{2}$-Synagis and $\left[{ }^{11} \mathrm{C}\right] \mathrm{PIB}$ are given in Table 2.

Deiodination of $\left[{ }^{124} \mathrm{I}\right] 8 \mathrm{D} 3-\mathrm{F}\left(\mathrm{ab}^{\prime}\right)_{2}$-h158 was assessed in the injection solution before the experiment and in plasma samples from injected animals after PET experiments, by separation with Zeba mini desalting columns, where free iodine was trapped in the column.

Ex vivo studies. Mice were anaesthetized with isoflurane at $2,4,24$ or $72 \mathrm{~h}$ after a single i.p. injection of $\left[{ }^{125} \mathrm{I}\right] \mathrm{F}\left(\mathrm{ab}^{\prime}\right)_{2}$-h158, $\left[{ }^{125} \mathrm{I}\right] 8 \mathrm{D} 3,\left[{ }^{125} \mathrm{I}\right] \mathrm{Fab}-8 \mathrm{D} 3,\left[{ }^{125} \mathrm{I}\right] 8 \mathrm{D} 3-$ $\mathrm{F}\left(\mathrm{ab}^{\prime}\right)_{2}-\mathrm{h} 158$ or $8 \mathrm{D} 3-\mathrm{F}\left(\mathrm{ab}^{\prime}\right)_{2}$-Synagis. A blood sample was obtained from the heart followed by intracardiac perfusion with $50 \mathrm{ml}$ physiological saline during $2 \mathrm{~min}$ Following perfusion, brains were isolated and the left hemisphere immediately frozen. The right hemisphere was either immediately frozen (for ex vivo autoradiography) or left to incubate in $4 \%$ paraformaldehyde for $24 \mathrm{~h}$, before it was immersed in a sucrose gradient (10,20 and 30\%) in PBS for cryoprotection (for immunohistochemistry) before being sectioned on a cryostat at $-20^{\circ} \mathrm{C}$.

In addition to the terminal blood samples obtained in all animals, blood samples $(8 \mu \mathrm{l})$ were obtained from the tail vein for a subset of animals also at $0.5,1$, $2,3,4,6,8,24,48$ and $72 \mathrm{~h}$ after injection.

Radioactivity in blood samples and in the frozen brain hemisphere was measured with a $\gamma$-counter (1480 Wizard, Wallac Oy, Turku, Finland). The brain and blood concentrations, quantified as \% ID per g tissue, were calculated as follows:

$\%$ ID per $g=$ measured radioactivity per gram brain tissue (or blood)/injected radioactivity.

In addition, the brain-to-blood $\left(K_{\mathrm{p}}\right)$ concentration ratio was calculated as follows:

$K_{\mathrm{p}}=$ measured radioactivity per gram brain tissue/measured radioactivity per gram blood.

The number of transgenic and WT animals included in the ex vivo and PET studies and injected radioactivities of the different radioligands are given in Table 2. Values for \% ID per $\mathrm{g}$ and $K_{\mathrm{p}}$ are summarized in Table 1 .

Positron emission tomography. In vivo brain distribution of $\left[{ }^{124} \mathrm{I}\right] 8 \mathrm{DD} 3-\mathrm{F}\left(\mathrm{ab}^{\prime}\right)_{2^{-}}$ h158 in tg-ArcSwe $(n=13)$, tg-Swe $(n=4)$, WT $(n=13)$ and tg- $\alpha$-syn $(n=4)$ mice and of $\left[{ }^{124} \mathrm{I}\right] 8 \mathrm{D} 3-\mathrm{F}\left(\mathrm{ab}^{\prime}\right)_{2}$-Synagis in tg-ArcSwe $(n=2)$ and WT $(n=1)$ was visualized with PET during $60 \mathrm{~min} 72 \mathrm{~h}$ post i.p. administration of respective radioligand. The day before injection of ${ }^{124} \mathrm{I}$-labelled fusion protein, animals were given water supplemented with $0.2 \% \mathrm{NaI}$ to reduce thyroidal uptake of ${ }^{124} \mathrm{I}$. A subset of the animals, $\operatorname{tg}-\operatorname{ArcSwe}(n=6), \operatorname{tg}$-Swe $(n=4)$ and WT $(n=4)$, were investigated with PET during $20 \mathrm{~min}$, starting $40 \mathrm{~min}$ after intravenous administration of $\left[{ }^{11} \mathrm{C}\right] \mathrm{PIB}, 1$ week before the $\left[{ }^{124} \mathrm{I}\right] 8 \mathrm{D} 3-\mathrm{F}\left(\mathrm{ab}^{\prime}\right)_{2}-\mathrm{h} 158$ scans.

At every scanning occasion, the animal was placed in the gantry of the animal PET/computed tomography (CT) scanner (Triumph Trimodality System, TriFoil Imaging, Inc., Northridge, CA, USA) and scanned in list mode followed by a CT examination for $3 \mathrm{~min}$ (field of view $=8.0 \mathrm{~cm}$ ). Mice were scanned in a random order.

The PET data were reconstructed using a maximum likelihood expectation maximization (MLEM) two-dimensional algorithm (10 iterations). The CT raw

Table 2 | Radioligand concentrations and injected doses.

\begin{tabular}{|c|c|c|c|c|}
\hline Radioligand & Labelling reaction yield (\%) & Specific activity $\left(\mathrm{MBq} \mathrm{nmol}^{-1}\right)$ & Injected radioactivity (MBq) & $\begin{array}{c}\text { Number of studied mice } \\
\text { (tg/WT) }\end{array}$ \\
\hline$[125 \mathrm{I}] \mathrm{F}\left(\mathrm{ab}^{\prime}\right)_{2}$ & $78 \pm 10$ & $130 \pm 36$ & $4.9 \pm 1.3$ & $3 / 3$ \\
\hline$\left[{ }^{125} I\right] 8 \mathrm{D} 3$ & $54 \pm 12$ & $55 \pm 10$ & $2.4 \pm 1.1$ & $4 / 7$ \\
\hline$\left[{ }^{125} \mid\right] F a b-8 D 3$ & $55 \pm 5.4$ & $25 \pm 4.8$ & $4.6 \pm 0.1$ & $2 / 4$ \\
\hline$\left[125\right.$ I] $8 \mathrm{D} 3-\mathrm{F}\left(\mathrm{ab}^{\prime}\right)_{2}-\mathrm{h} 158$ & $70 \pm 12$ & $136 \pm 24$ & $1.4 \pm 0.8$ & $29 / 26$ \\
\hline$\left.{ }^{124} \mid\right] 8 D 3-F\left(a b^{\prime}\right)_{2}-h 158$ & $74 \pm 3.7$ & $218 \pm 29$ & $14.5 \pm 1.6$ & $21^{\star} / 13$ \\
\hline$[125 \mid] 8 D 3-F\left(a b^{\prime}\right)_{2}$-Synagis & 43 & 116 & $0.8 \pm 0.2$ & $2 / 4$ \\
\hline$\left.{ }^{124} \mid\right] 8 D 3-F\left(a b^{\prime}\right)_{2^{-}}$ & 62 & 193 & $13.3 \pm 0.3$ & $2 / 1$ \\
\hline
\end{tabular}

Synagis

Radio-chemical purity (\%) Specific Activity ( $\mathrm{MBq} \mathrm{nmol}^{-1}$ ) Injected radioactivity (MBq) Number of studied mice (tg/WT)

\begin{tabular}{lllll}
\hline$\left[{ }^{11} \mathrm{C}\right] \mathrm{PIB}$ & $>95$ & $13 \pm 18$ & $8.5 \pm 4.4$ & $10 / 4$
\end{tabular}


files were reconstructed using filter back projection. All subsequent processing of the PET and CT images were performed in imaging software Amide 1.0.4 (ref. 52). The CT scan was manually aligned with a T2-weighted, magnetic resonance imaging-based mouse brain atlas ${ }^{53}$ containing outlined regions of interests for hippocampus, striatum, thalamus, cortex and cerebellum. The PET image was then aligned with the CT, and thus, the magnetic resonance imaging atlas was also aligned with the PET data. The PET data shown in Figs 5a,c,d and 7a-c are summed images, that is, representing the average activity during the whole PET scan. The PET data were quantified as a concentration ratio of the radioactivity in five regions of interest (whole brain, cortex, hippocampus, thalamus and striatum) to that in cerebellum.

Biochemical and histopathological analyses. Brain concentrations of soluble $A \beta$ and total $A \beta$ were measured as described previously ${ }^{18}$. In short, mice were saline perfused and the left hemisphere of each animal was homogenized at a 1:5 weight:volume ratio in TBS with complete protease inhibitors (Roche), using a tissue grinder with Teflon pestle $(2 \times 10$ strokes on ice). A volume of $400 \mu$ l of each sample was mixed with $400 \mu \mathrm{l}$ TBS and centrifuged for $1 \mathrm{~h}$ at $16,000 \mathrm{~g}$ to obtain a preparation of soluble proteins. The supernatants were aliquoted and stored at $-80^{\circ} \mathrm{C}$ until analysis. To obtain a preparation including insoluble proteins found in amyloid plaques, $270 \mu \mathrm{l}$ of the original TBS extract was mixed with $730 \mu \mathrm{l}$ of concentrated formic acid, to a final formic acid concentration of $70 \%$, followed by homogenization and centrifugation as above.

In the $\mathrm{A} \beta$ protofibril ELISA, 96-well plates were coated overnight with $200 \mathrm{ng}$ per well $\mathrm{mAb} 158$, and blocked with 1\% BSA in PBS. TBS extracts were diluted 1:25 and incubated overnight at $+4^{\circ} \mathrm{C}$, followed by detection with biotinylated mAb158 $\left(0.5 \mu \mathrm{g} \mathrm{ml}^{-1}\right)$ and streptavidin-HRP (1:2,000; Mabtech AB). Signals were developed with K blue aqueous TMB substrate (Neogen Corp., Lexington, KY, USA) and read with a spectrophotometer at $450 \mathrm{~nm}$.

For ELISA measurement of $A \beta x-40$ and $A \beta x-42$, 96-well plates were coated overnight with $100 \mathrm{ng}$ per well of polyclonal rabbit anti-A $\beta 40$ or anti-A $\beta 42$ (Agrisera, Umeå, Sweden), and blocked with $1 \%$ BSA in PBS. Formic acid extracts were neutralized with $2 \mathrm{M}$ Tris and diluted 500-50,000 times depending on $\mathrm{A} \beta$ content and incubated overnight at $+4^{\circ} \mathrm{C}$, followed by detection with biotinylated mAblC3 $\left(0.5 \mu \mathrm{g} \mathrm{ml}^{-1}\right)^{25,26}$ and streptavidin-HRP (1:5,000; Mabtech AB). Signals were developed and read as above. All sample and secondary antibody dilutions were made in ELISA incubation buffer (PBS with 0.1\% BSA, 0.05\% Tween and 0.15\% Kathon).

CD31 immunohistochemistry and nuclear track emulsion autoradiography were performed on semi-adjacent sections $(20 \mu \mathrm{m})$ of the right hemisphere, immunostained for the endothelial marker $\mathrm{CD} 31$. First, sections were washed in PBS and incubated with $3 \% \mathrm{H}_{2} \mathrm{O}_{2}$ and $10 \%$ methanol in water for $15 \mathrm{~min}$. Nonspecific binding was then blocked using 3\% BSA in PBS-Tween $(0.1 \%)$ for $1 \mathrm{~h}$, followed by an overnight incubation with $0.5 \mu \mathrm{g} \mathrm{ml}^{-1}$ rat anti-mouse $\mathrm{CD} 31$ (550274, BD Biosciences, San Jose, CA, USA) at $4{ }^{\circ} \mathrm{C}$. The sections were then incubated with $5 \mu \mathrm{g} \mathrm{ml}^{-1}$ biotinylated goat anti-rat (BA-9400, Vector Laboratories Inc., Burlingame, CA) for $1 \mathrm{~h}$ at room temperature, followed by PBS washes and a 45-min incubation with avidin/biotin complex (Vector Laboratories). The staining was then visualized with a 3-min 3,3'-diaminbenzidine (DAB) development, for some sections followed by immersion in Congo red for $45 \mathrm{~min}$. Sections were then dehydrated in ethanol (70, 95 and 100\%) and left to air dry.

Immediately after $\mathrm{CD} 31$ and Congo staining, sections were immersed for $3 \mathrm{~s}$ in Ilford K5 emulsion $\left(40^{\circ} \mathrm{C}\right)$, left to air dry for $2 \mathrm{~h}$ and stored at $+4{ }^{\circ} \mathrm{C}$ protected from light. Sections were then developed with Ilford photographic reagents, briefly counterstained with haematoxylin, dehydrated with ethanol and xylene, and mounted with DPX mounting medium.

Ex vivo autoradiography. After PET imaging, a subset of the $\left.{ }^{124} \mathrm{I}\right] 8 \mathrm{D} 3-\mathrm{F}\left(\mathrm{ab}^{\prime}\right)_{2-}$ h158-injected mice and the $\left[{ }^{124} \mathrm{I}\right] 8 \mathrm{D} 3-\mathrm{F}\left(\mathrm{ab}^{\prime}\right)_{2}$-Synagis-injected mice was selected for ex vivo autoradiography directly after PET imaging. Following saline perfusion, the right hemisphere was instantly frozen and cryosectioned $(20 \mu \mathrm{m})$. Two sections from each animal and ${ }^{124} \mathrm{I}$-abelled standards of known radioactivity were placed in an X-ray cassette and exposed to positron-sensitive phosphor screens (MS, MultiSensitive, PerkinElmer, Downers grove, IL, USA) for 4 days. The plates were scanned in a Cyclone Plus Imager system (Perkin Elmer) at a resolution of 600 dots per inch. The resulting digital images were normalized to the standards and converted to a false colour scale (Royal) with ImageJ for comparison with PET images.

Statistics. Results reported are presented as mean \pm s.d. Data were analysed with two-way analysis of variance followed by Bonferroni's post hoc test. In cases where the variance was different in the different groups (variance was in general larger in tg-ArcSwe mice than in WT mice), data were log-transformed before analysis to adhere with the analysis of variance assumption of equal variance. Pearson's correlation was used to analyse correlation of brain uptake of radioligands and $A \beta$ protofibril concentrations.

Study approval. All procedures described in this paper were approved by the Uppsala County Animal Ethics Board (\#C216/11, \#C110/11 and \#C17/14), following the rules and regulations of the Swedish Animal Welfare Agency, and were in compliance with the European Communities Council Directive of 22
September 2010 (2010/63/EU). All efforts were made to minimize animal suffering and to reduce the number of animals used.

\section{References}

1. Klunk, W. E. et al. Imaging brain amyloid in Alzheimer's disease with Pittsburgh Compound-B. Ann. Neurol. 55, 306-319 (2004).

2. Fagan, A. M. et al. Inverse relation between in vivo amyloid imaging load and cerebrospinal fluid Abeta42 in humans. Ann. Neurol. 59, 512-519 (2006).

3. Engler, H. et al. In vivo amyloid imaging with PET in frontotemporal dementia. Eur. J. Nucl. Med. Mol. Imaging 35, 100-106 (2008).

4. Rabinovici, G. D. et al. 11C-PIB PET imaging in Alzheimer disease and frontotemporal lobar degeneration. Neurology 68, 1205-1212 (2007).

5. Engler, H. et al. Two-year follow-up of amyloid deposition in patients with Alzheimer's disease. Brain 129, 2856-2866 (2006).

6. Terry, R. D. et al. Physical basis of cognitive alterations in Alzheimer's disease: synapse loss is the major correlate of cognitive impairment. Ann. Neurol. 30, 572-580 (1991).

7. McLean, C. A. et al. Soluble pool of Abeta amyloid as a determinant of severity of neurodegeneration in Alzheimer's disease. Ann. Neurol. 46, 860-866 (1999).

8. Näslund, J. et al. Correlation between elevated levels of amyloid beta-peptide in the brain and cognitive decline. JAMA 283, 1571-1577 (2000).

9. Fukumoto, H. et al. High-molecular-weight beta-amyloid oligomers are elevated in cerebrospinal fluid of Alzheimer patients. FASEB J. 24, 2716-2726 (2010).

10. Esparza, T. J. et al. Amyloid-beta oligomerization in Alzheimer dementia versus high-pathology controls. Ann. Neurol. 73, 104-119 (2013).

11. Lannfelt, L., Relkin, N. R. \& Siemers, E. R. Amyloid- $\beta$-directed immunotherapy for Alzheimer's disease. J. Intern. Med. 275, 284-295 (2014).

12. Goure, W. F., Krafft, G. A., Jerecic, J. \& Hefti, F. Targeting the proper amyloidbeta neuronal toxins: a path forward for Alzheimer's disease immunotherapeutics. Alzheimers Res. Ther. 6, 42 (2014).

13. Lannfelt, L. et al. Perspectives on future Alzheimer therapies: amyloid-beta protofibrils-a new target for immunotherapy with BAN2401 in Alzheimer's disease. Alzheimers Res. Ther. 6, 16 (2014).

14. Viola, K. L. \& Klein, W. L. Amyloid beta oligomers in Alzheimer's disease pathogenesis, treatment, and diagnosis. Acta Neuropathol. 129, 183-206 (2015)

15. Viola, K. L. et al. Towards non-invasive diagnostic imaging of early-stage Alzheimer's disease. Nat. Nanotechnol. 10, 91-98 (2015).

16. Salvadores, N., Shahnawaz, M., Scarpini, E., Tagliavini, F. \& Soto, C. Detection of misfolded Abeta oligomers for sensitive biochemical diagnosis of Alzheimer's disease. Cell Rep. 7, 261-268 (2014).

17. Wang-Dietrich, L. et al. The amyloid-beta oligomer count in cerebrospinal fluid is a biomarker for Alzheimer's disease. J. Alzheimers Dis. 34, 985-994 (2013).

18. Sehlin, D. et al. Large aggregates are the major soluble Abeta species in $A D$ brain fractionated with density gradient ultracentrifugation. PLOS ONE 7, e32014 (2012).

19. Nilsberth, C. et al. The 'Arctic' APP mutation (E693G) causes Alzheimer's disease by enhanced Abeta protofibril formation. Nat. Neurosci. 4, 887-893 (2001).

20. Walsh, D. M. et al. Naturally secreted oligomers of amyloid beta protein potently inhibit hippocampal long-term potentiation in vivo. Nature 416, 535-539 (2002).

21. Klyubin, I. et al. Amyloid beta protein dimer-containing human CSF disrupts synaptic plasticity: prevention by systemic passive immunization. J. Neurosci. 28, 4231-4237 (2008).

22. Shankar, G. M. et al. Amyloid-beta protein dimers isolated directly from Alzheimer's brains impair synaptic plasticity and memory. Nat. Med. 14, 837-842 (2008).

23. Fowler, S. W. et al. Genetic modulation of soluble Abeta rescues cognitive and synaptic impairment in a mouse model of Alzheimer's disease. J. Neurosci. 34, 7871-7885 (2014).

24. van Dongen, G. A., Poot, A. J. \& Vugts, D. J. PET imaging with radiolabeled antibodies and tyrosine kinase inhibitors: immuno-PET and TKI-PET. Tumour Biol. 33, 607-615 (2012).

25. Englund, H. et al. Sensitive ELISA detection of amyloid-beta protofibrils in biological samples. J. Neurochem. 103, 334-345 (2007).

26. Sehlin, D. et al. Heavy-chain complementarity-determining regions determine conformation selectivity of anti-abeta antibodies. Neurodegener. Dis. 8, 117-123 (2011).

27. Magnusson, K. et al. Specific uptake of an amyloid-beta protofibril-binding antibody-tracer in AbetaPP transgenic mouse brain. J. Alzheimers Dis. 37, 29-40 (2013).

28. Tucker, S. et al. The murine version of BAN2401 (mAb158) selectively reduces amyloid-beta protofibrils in brain and cerebrospinal fluid of tg-ArcSwe mice. J. Alzheimers Dis. 43, 575-588 (2014).

29. Lord, A. et al. The Arctic Alzheimer mutation facilitates early intraneuronal Abeta aggregation and senile plaque formation in transgenic mice. Neurobiol. Aging 27, 67-77 (2006). 
30. Poduslo, J. F., Curran, G. L. \& Berg, C. T. Macromolecular permeability across the blood-nerve and blood-brain barriers. Proc. Natl Acad. Sci. USA 91, 5705-5709 (1994).

31. Wu, D. \& Pardridge, W. M. Neuroprotection with noninvasive neurotrophin delivery to the brain. Proc. Natl Acad. Sci. USA 96, 254-259 (1999).

32. Yu, Y. J. et al. Boosting brain uptake of a therapeutic antibody by reducing its affinity for a transcytosis target. Sci. Transl. Med. 3, 84ra44 (2011).

33. Yu, Y. J. et al. Therapeutic bispecific antibodies cross the blood-brain barrier in nonhuman primates. Sci. Transl. Med. 6, 261 ra154 (2014).

34. Niewoehner, J. et al. Increased brain penetration and potency of a therapeutic antibody using a monovalent molecular shuttle. Neuron 81, 49-60 (2014).

35. Lee, H. J., Engelhardt, B., Lesley, J., Bickel, U. \& Pardridge, W. M. Targeting rat anti-mouse transferrin receptor monoclonal antibodies through blood-brain barrier in mouse. J. Pharmacol. Exp. Ther. 292, 1048-1052 (2000).

36. Kissel, K. et al. Immunohistochemical localization of the murine transferrin receptor (TfR) on blood-tissue barriers using a novel anti-TfR monoclonal antibody. Histochem. Cell Biol. 110, 63-72 (1998).

37. Lee, H. J., Zhang, Y., Zhu, C., Duff, K. \& Pardridge, W. M. Imaging brain amyloid of Alzheimer disease in vivo in transgenic mice with an Abeta peptide radiopharmaceutical. J. Cereb. Blood Flow Metab. 22, 223-231 (2002).

38. Zhang, Y. \& Pardridge, W. M. Delivery of beta-galactosidase to mouse brain via the blood-brain barrier transferrin receptor. J. Pharmacol. Exp. Ther. 313, 1075-1081 (2005).

39. Boado, R. J., Zhang, Y., Wang, Y. \& Pardridge, W. M. Engineering and expression of a chimeric transferrin receptor monoclonal antibody for bloodbrain barrier delivery in the mouse. Biotechnol. Bioeng. 102, 1251-1258 (2009).

40. Cabezon, I. et al. Trafficking of gold nanoparticles coated with the 8D3 antitransferrin receptor antibody at the mouse blood-brain barrier. Mol. Pharm. 12, 4137-4145 (2015).

41. Koffie, R. M. et al. Oligomeric amyloid $\beta$ associates with postsynaptic densities and correlates with excitatory synapse loss near senile plaques. Proc. Natl Acad. Sci. USA 106, 4012-4017 (2009).

42. Philipson, O. et al. A highly insoluble state of Abeta similar to that of Alzheimer's disease brain is found in Arctic APP transgenic mice. Neurobiol. Aging 30, 1393-1405 (2009).

43. Lord, A. et al. An amyloid-beta protofibril-selective antibody prevents amyloid formation in a mouse model of Alzheimer's disease. Neurobiol. Dis. 36, 425-434 (2009)

44. Bussiere, T. et al. Morphological characterization of thioflavin-S-positive amyloid plaques in transgenic Alzheimer mice and effect of passive Abeta immunotherapy on their clearance. Am. J. Pathol. 165, 987-995 (2004).

45. Ingelsson, M. et al. Early Abeta accumulation and progressive synaptic loss, gliosis, and tangle formation in AD brain. Neurology 62, 925-931 (2004).

46. Schöll, M. et al. Low PiB PET retention in presence of pathologic CSF biomarkers in Arctic APP mutation carriers. Neurology 79, 229-236 (2012).

47. von Pawel-Rammingen, U., Johansson, B. P. \& Bjorck, L. IdeS, a novel streptococcal cysteine proteinase with unique specificity for immunoglobulin G. EMBO J. 21, 1607-1615 (2002).

48. Lord, A. et al. Amyloid-beta protofibril levels correlate with spatial learning in Arctic Alzheimer's disease transgenic mice. FEBS J. 276, 995-1006 (2009).
49. Kahle, P. J. et al. Subcellular localization of wild-type and Parkinson's disease-associated mutant alpha-synuclein in human and transgenic mouse brain. J. Neurosci. 20, 6365-6373 (2000).

50. Greenwood, F. C., Hunter, W. M. \& Glover, J. S. The preparation of I-131labelled human growth hormone of high specific radioactivity. Biochem. J. 89, 114-123 (1963).

51. Bolton, A. E. \& Hunter, W. M. The labelling of proteins to high specific radioactivities by conjugation to a $125 \mathrm{I}$-containing acylating agent. Biochem. J. 133, 529-539 (1973).

52. Loening, A. M. \& Gambhir, S. S. AMIDE: a free software tool for multimodality medical image analysis. Mol. Imaging 2, 131-137 (2003).

53. Ma, Y. et al. A three-dimensional digital atlas database of the adult C57BL/6 J mouse brain by magnetic resonance microscopy. Neuroscience 135, 1203-1215 (2005).

\section{Acknowledgements}

We are grateful to L. Nilsson who developed the mouse models, to V. Tolmachev A. Orlova, S. Estrada, V. Asplund, R.K. Selvaraju, O. Eriksson, A. Bergmann, M. Sterby, S. Ololo and D. Edén for technical and experimental assistance, to BioArctic Neuroscience $\mathrm{AB}$ for providing a $\mathrm{F}\left(\mathrm{ab}^{\prime}\right)_{2}$ fragment of the humanized variant (BAN2401) of mAb158 and to P. O'Callaghan for comments on the manuscript. This work was supported by grants from the Swedish Research Council (\#2012-1593, \#2012-2172), Alzheimerfonden, Hjärnfonden, Svenska Lundbeck-stiftelsen, Åhlén-stiftelsen, Stohnes stiftelse and Uppsala Berzelii Technology Centre for Neurodiagnostics.

\section{Author contributions}

D.S. and S.S. designed the project; L.L. and G.A. contributed to the study design; D.S. generated the fusion protein and performed in vitro binding experiments; D.S., X.T.F., L.C. and S.S. performed all brain uptake and PET studies; X.T.F. performed immunohistochemistry experiments; D.S. and S.S. analysed data and wrote the manuscript, with valuable input from X.T.F., L.C., G.A. and L.L.

\section{Additional information}

Competing financial interests: L.L. is a founder of BioArctic Neuroscience and has shares in the company. The remaining authors declare no competing financial interests.

Reprints and permission information is available online at http://npg.nature.com/ reprintsandpermissions/

How to cite this article: Sehlin, D. et al. Antibody-based PET imaging of amyloid beta in mouse models of Alzheimer's disease. Nat. Commun. 7:10759 doi: 10.1038/ncomms10759 (2016)

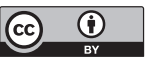

This work is licensed under a Creative Commons Attribution 4.0 International License. The images or other third party material in this article are included in the article's Creative Commons license, unless indicated otherwise in the credit line; if the material is not included under the Creative Commons license, users will need to obtain permission from the license holder to reproduce the material. To view a copy of this license, visit http://creativecommons.org/licenses/by/4.0/ 